Continuing the Discussion of the Spiroans and Their Entrepots: A Reply to Brooks's Critique of My New Paradigm/or the Archeology of the Arkansas Valley

Frank Schambach

Arkansas Archaeological Survey

Follow this and additional works at: https://scholarworks.sfasu.edu/ita

Part of the American Material Culture Commons, Archaeological Anthropology Commons, Environmental Studies Commons, Other American Studies Commons, Other Arts and Humanities Commons, Other History of Art, Architecture, and Archaeology Commons, and the United States History Commons

Tell us how this article helped you.

This Article is brought to you for free and open access by the Center for Regional Heritage Research at SFA ScholarWorks. It has been accepted for inclusion in Index of Texas Archaeology: Open Access Gray Literature from the Lone Star State by an authorized editor of SFA ScholarWorks. For more information, please contact cdsscholarworks@sfasu.edu. 
Continuing the Discussion of the Spiroans and Their Entrepots: A Reply to Brooks's Critique of My New Paradigm/or the Archeology of the Arkansas Valley

Creative Commons License

(c) (1) (9)

This work is licensed under a Creative Commons Attribution-NonCommercial 4.0 International License 


\title{
Continuing the Discussion of the Spiroans and Their Entrepots: A Reply to Brooks's Critique of My New Paradigm for the Archeology of the Arkansas Valley
}

\author{
Frank Schambach \\ Arkansas Archeological Survey
}

Although Brooks (1996) seems to agree with me that the archeology of the Arkansas Valley requires a new paradigm ${ }^{1}$, he clearly believes that mine (Schambach 1993) -- which he apparently considers a poorly founded Binfordian screed written primarily for its shock value -- is not the one. Where, according to Brooks, have I gone wrong in my work on the archeology of the Arkansas Valley? Which of my generalizations does he consider so poorly grounded empirically as to suggest, as he insinuates, professionally and perhaps even ethically questionable work, and in what ways does he consider them deficient?

First and, evidently, foremost among the four major aspects of my work with which he takes issue, Brooks objects to my characterization (Schambach 1993:189) of the subsistence system ${ }^{2}$ of the Arkansas Valley tradition from A. D. 1100 on as "significantly more diverse" than "traditions to the east or south", as "featuring hoe horticulture of most of the plants of the old Woodland period 'Cultivated Starchy Seed Complex' of the Ozark highlands plus some corn," and as including, "probably" as an important part of the economy, "bison hunting ${ }^{3}$ for food, hides and bone tools such as scapula hoes ... by no later than A. D 1100". Brooks particularly objects to the latter. Trotting out all of the old arguments that I tried to lay to rest in my 1993 resynthesis of the Arkansas Valley tradition (that bison bones are only important numerically in Fort Coffee phase contexts ${ }^{4}$; that the School Land sites were marginal culturally and environmentally ${ }^{5}$; that there aren't enough bones from eastern Oklahoma sites to indicate that bison were important to people living in that area during the Mississippi period, etc.), Brooks argues that "there is no supportive evidence for bison ${ }^{6}$ as a food staple during Harlan and/or Spiro phase ${ }^{7}$ times." I wouldn't know whether bison was a "food staple" for the Harlan and Spiro phase people. But I stand by my welldocumented assessment that Harlan and Spiro phase people were "substantial consumers of bison products and were processing bison hides from A.D. 1100 on". That assessment would not appear to be as far out of line with the evidence as Brooks thinks, since Brown (1996:29) has recently concluded that "the appearance of a bone or two of bison as early as the Harlan phase context at the Copple mound signals the possible existence of longdistance procurement or some form of distant exchange", and that "the appear- 
ance of one or two bison bones in Spiro phase middens signals the shift, at least partially, to upland [prairie bison] hunting".

Brooks's only quarrel with me in his rambling discussion of Spiroan horticulture stems from his misperception that I consider the Spiroans "minor horticulturalists". Thus he asks: Why would people with "only a minor emphasis on agriculture" (1996:19) need hoes ${ }^{8}$ at all? I don't know. Nor is that a question I need to answer since -- as I've already pointed out -- I view their subsistence system as one which "featured hoe horticulture of most of the plants of the old Woodland period 'Cultivated Starchy Seed Complex' plus some corn" (Schambach 1993:189). To me that means they relied substantially on horticulture, although compared to the Mississippians to the east and the Caddo to the south they did not use much corn. Brooks dislikes the idea that corn was not, as Arkansas Valley specialists (and the rest of us) have long imagined, a major element in the Spiroan diet. But it appears that he will have to get used to it because leading Arkansas Valley archeologists seem to be lining up with me on this point. Recently published evaluations by Brown (1996) and Rogers (1996) of the new paleobotanical data from the Arkansas Valley reach essentially the same conclusions I published in 1993. Rogers (1996:60) states that although recent dates suggest that maize in the Arkansas was "increasing in dietary importance by A.D. 1000 and becoming significant by A.D. 1300", "most paleobotanical evidence points to the existence of a mixed economy of wild and domesticated plant foods with less reliance on maize in comparison to other areas of the Southeast". And, as Brown (1996:31) puts it, citing Fritz, in the Arkansas Valley "maize did not rise to importance as a crop until A.D. 1200". "Maize agriculture", was not, Brown states (1996:31), the "essential economic underpinning to the complexity that was visualized" for the Arkansas Valley during the Mississippi period. Furthermore he concludes (1996: 200 ) that: "The absence of an economy focused upon maize points to Spiro having a social evolution distinctly different from that of contemporary centers in the Mississippi Valley and in the Deep South. That means that arguments used to explain the evolutionary development behind Cahokia and Moundville have to be modified for Spiro, and perhaps, even to be replaced altogether". Indeed! The new explanation I have offered for the "evolutionary development behind" Spiro ${ }^{10}$ is that the Spiroans were long distance traders in buffalo products, Osage orange bows and Mississippian prestige goods.

Thus my point in discussing the subsistence base of the Arkansas Valley originally -- that the people of the Arkansas Valley had a subsistence system that was significantly different from that of the Caddo area to the south and the Mississippi Valley to the east -- appears to be valid and is reaching general acceptance ${ }^{11}$. Brown (1996:31) has reinforced that point by noting that the corn being grown in the Arkansas Valley was itself "distinctive in possessing a disproportionate percentage of 12-row cobs and few large 8-row cobs" which "separates the Arkansas Valley/ 
Ozarks from the East in general ${ }^{12 "}$.

Brooks's second major criticism of my new paradigm stems from his misunderstanding of my discussion (Schambach $1993: 192-193 ; 204)$ of the possible cultural significance of the fact, well-known to bioanthropologists, that compared to those from the Caddo area to the south, Mississippi period skeletal populations from the Arkansas Valley exhibit an extraordinary high incidence of bone lesions indicating the presence of endemic syphilis. Operating, it would appear, with inadequate knowledge of the relevant bioanthropological literature, Brooks has jumped to the conclusion that endemic syphilis is "a sexually transmitted disease, in this case venereal syphilis" (Brooks 1996:20). This elementary but serious error -- as I explain in the paper in question (Schambach 1993:204, endemic syphilis is a non-venereal "contagious disease of childhood" (Hackett 1963:10; Grieco 1995:30, Table 1; Rothschild and Rothschild 1996:556) ${ }^{13}$-- reveals that Brooks is not qualified to challenge me (and, indeed, the bioanthropological literature in general) on this issue. The conclusions that he draws while laboring in ignorance of the nature and etiology of endemic syphilis are, of course, absurd, particularly his conclusion (1996:21) that "Most, if not all, late prehistoric groups across Oklahoma, portions of Texas, and yes, even portions of Arkansas probably had this condition [i.e., venereal syphilis] as well". It is true, as Brooks states, that bioanthropologists do not consider osteitis diagnostic of "syphilis", by which he means venereal syphilis. But neither I nor anyone else who knows anything about the treponemal diseases would ever say they did. I said, citing Burnett's overview article (1988:212-214), that bioanthropologists consider the unusually high incidence of osteitis in Arkansas Valley populations indicative of "a high incidence of endemic syphilis or some other treponemal infection" (Schambach 1993:204). That is a simple statement of fact, not refutable by Brooks or anyone else. So is my observation (Schambach 1993:193) that, according to four bioanthropologists (Harmon and Rose 1989:347-349; Burnett 1988:215-216 and Brues 1958, 1959), the Arkansas Valley was a hotbed of infection during the Mississippi period, while infection rates in the Caddo area to the south were remarkably low. In the face of this consensus Brooks's (1996:21) insistence that "we should be highly skeptical of the absence of syphilis-like attributes [whatever he might mean by that] among Caddo populations in Arkansas and Louisiana" is merely indicative of the absurd lengths to which he and other defenders of the old "Arkansas Valley Caddoan" paradigm must now go to keep it alive in the face of steadily accumulating contradictory data. They are now in the position of having to ignore or deny virtually all of the bioanthropological data since it indicates that the Arkansas Valley and the Caddo area to the south were inhabited by two distinct populations with different diets, different health problems, different congenital anomalies and, as we have recently learned (Wilson and Derrick 1996; Schambach 1996) different styles of cranial deformation. 
And, to proceed to the third major point on which Brooks has challenged my new paradigm, I maintain that these populations had thoroughly different cultures as well, although both conformed generally to the Southeastern pattern. But Brooks and other defenders of the old paradigm (see Bruseth, Wilson and Perttula 1995) do not see this. The main reason they do not seems to be that they have yet to realize the extent to which Krieger (1946) mistakenly obscured the profound cultural differences between the Arkansas Valley and the Red River Valley in northeast Texas and southeast Oklahoma by misinterpreting the Sanders site as the type site for a still hypothetical "Sanders focus ${ }^{14}$ that supposedly developed in the Red River Valley early in the Mississippi period. This bogus focus is, of course, very Arkansas Valley-like because the single component at Sanders on which it is based represents a site unit intrusion of Spiroans from the Arkansas Valley (Schambach 1993:203-208; 1995).

One of the more important of the numerous clues that the cultural component of the Sanders mortuary assemblage represents an intrusion of Spiroans is the red slipped "Sanders Plain" pottery it contains, the pottery Brooks (1996:21) thinks "is not that big a deal". I (Schambach 1993:212-213) consider it an Arkansas Valley variety of the widespread Mississippian type Old Town Red because, as Brown (1996:403-405) has recently reaffirmed, the 25 whole and fragmentary bowls of Old Town Red he identifies in the Spiro collections are unsortable from the Sanders Plain pots from Spiro in every attribute except base shape. In my view, the Sanders Plain from the Sanders site was imported to Sanders from Spiro ${ }^{15}$ along with almost everything else in the Sanders mortuary assemblage, including almost all of the other pottery ${ }^{16}$.

I base the latter opinion partly on the fact that, contrary to the conventional wisdom -- voiced accurately, although awkwardly, by Brooks (1996:21) -- it is not true that "the red slipped wares that characterize the ceramic assemblage found at Spiro and other Spiro phase settlements" in the Arkansas Valley are "found in abundance in the Red River Valley in the twelfth and thirteenth centuries" where they are "associated with the Sanders site as well as numerous other villages and mound sites on both sides of the Red River". In reality, the red slipped, so-called "Sanders focus" ${ }^{17}$ types Sanders Plain, Sanders Engraved and Maxey Noded Redware are rarely found in the Red River Valley, except at the Sanders site ${ }^{18}$. Occurrences of bona fide specimens of these types at southeast Oklahoma and northeast Texas sites other than Sanders are too infrequent and the types themselves are too erratically represented to support the concept of a Sanders focus (Krieger 1946), or phase (see Bruseth, Wilson and Perttula 1995).

Even the raw data on the distribution of so-called Sanders focus pottery in this area support this generalization. These are summarized in Table $1^{19}$, my compilation of all the pottery of all the supposedly diagnostic "Sanders focus" types reported from the 23 sites which, according to Bruseth, Wilson, and Perttula (1995:228, 
Volume 7, Number 4

Table 1 .

\begin{tabular}{|c|c|c|c|c|c|c|}
\hline Holdeman & $\begin{array}{l}\text { Canton } \\
\text { Incised }\end{array}$ & $\begin{array}{l}\text { Sasoders } \\
\text { Engraved }\end{array}$ & $\begin{array}{l}\text { Marrey } \\
\text { Noded }\end{array}$ & Monkstown & $\begin{array}{l}\text { Seadern } \\
\text { Pintn }\end{array}$ & $\begin{array}{l}\text { Shends of } \\
\text { all types } \\
\text { at sites }\end{array}$ \\
\hline A. Meckin & 1 & - & 1 & - & 28 & 340 \\
\hline Beldwin & 2 & . & 5 & - & 39 & 1263 \\
\hline Beaver & 37 & 7 & 8 & - & 818 & 5385 \\
\hline Bell & - & 4 & - & - & 10 & 1095 \\
\hline Clemens & $\because$ & - & - & . & - & - \\
\hline Cook & 1 & - & - & - & - & 62 \\
\hline E. Johnson & 29 & 12 & 4 & - & $\begin{array}{c}301 \\
2 \text { pots }\end{array}$ & 5690 \\
\hline Fauken & - & - & - & - & - & - \\
\hline Gregory & 10 & - & - & - & 15 & 123 \\
\hline Harling & - & - & . & - & . & 0 \\
\hline \multirow[t]{2}{*}{ Hines } & 9 & 4 & - & - & - & 13,781 \\
\hline & 4 pots & 2 pots & 5 pots & - & - & 195 pots \\
\hline Keufman & 4 & 1 & - & - & 29 & 1655 \\
\hline Mahaffey & $\begin{array}{c}41 \\
1 \text { pot }\end{array}$ & - & - & 1 & 13 & 1502 \\
\hline Nelson & 83 & - & 3 & - & 79 & 398 \\
\hline Pat Boyd & 289 & 9 & 18 & - & 252 & 4648 \\
\hline Payne & 12 & - & - & - & 532 & $\cdot$ \\
\hline Pine Croek & - & 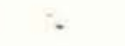 & - & - & 10 & 503 \\
\hline Spoonbill & 30 & $\begin{array}{c}12 \\
2 \text { pots }\end{array}$ & . & 2 pots & - & 25,811 \\
\hline Teddlock & $\begin{array}{c}759 \\
5 \text { pots }\end{array}$ & 290 & - & - & - & 18,394 \\
\hline T. Moody & - & - & - & - & - & - \\
\hline Woods Mound & - & - & - & - & * & 21,516 \\
\hline Yarbrough & $\begin{array}{c}126 \\
1 \text { pot }\end{array}$ & $\begin{array}{c}45 \\
1 \text { pot }\end{array}$ & - & 1 & $\begin{array}{c}89 \\
7 \text { pots }\end{array}$ & 693 \\
\hline TOTAL & $\begin{array}{c}1433 \\
11 \text { pots }\end{array}$ & $\begin{array}{c}384 \\
5 \text { pots }\end{array}$ & $\begin{array}{c}39 \\
5 \text { pots }\end{array}$ & $\stackrel{2}{2}$ & $\begin{array}{l}2215 \\
9 \text { pots }\end{array}$ & 109,727 \\
\hline
\end{tabular}


Table 1), comprise the complete list of northeast Texas and southeast Oklahoma sites with "probable Sanders phase components $^{201}$. As Table 1 indicates, these sites have yielded only 384 sherds and 5 pots identified as Sanders Engraved, 39 sherds and 5 pots identified as Maxey Noded Redware and 2215 sherds and 9 pots identified as Sanders Plain. Thus only about $2.4 \%$ of all the pottery from them $(109,727$ sherds and 195 pots) is reportedly of red slipped "Sanders focus" types, not what I would call an "abundant" representation.

Judging from the collection of 74 whole pots of Sanders focus types from the graves and other contexts at Sanders (Krieger 1946: Table 6) -- the only basis on which this judgment can be made -- a Sanders focus ceramic assemblage (were there such a thing) would consist of approximately 3\% Canton Incised, 28\% Sanders Engraved, 22\% Maxey Noded Redware, 7\% Monkstown Fingernail Impressed and $41 \%$ Sanders Plain. But the collections from the 23 Red River Valley sites on Bruseth, Wilson and Perttula's list of sites with alleged Sanders focus components fail, singly and collectively, to meet these expectations. At none of them do even roughly similar assemblages of these types appear in valid archeological contexts. And when the distributions of these types at Red River Valley sites are considered individually and in detail it becomes apparent that they are dependent on several factors which have nothing to do with the representation of a major early Caddo "focus" or phase in the Red River Valley.
The best indication that this is true is the distribution of Maxey Noded Redware. Since that type accounts, as just noted, for $22 \%$ of the whole pots in the Sanders mortuary assemblage, it should be represented in respectable quantities in any real "Sanders focus" assemblage. Its meager representation by only 39 sherds $^{21}$ at only 5 of the 23 sites with "probable Sanders focus" components suggests two things. The first is that, because it is the "Sanders focus" type that is the most difficult to misidentify, there being no Red River Valley types that share its distinctive combination of attributes (red slip, nodes, and punctation on bottles), this is probably the most realistic of the figures we have for the distribution of any of the so-called "Sanders focus" pottery types in the Red River Valley. The second is that the few pots represented by these sherds are probably the remains of a relatively small number of pots of this Arkansas Valley type that local Caddos obtained in trade from the Spiroans who were operating the Sanders entrepot.

Considering that it represents $28 \%$ of the Sanders mortuary collection, Sanders Engraved is also incredibly weakly represented at so-called Sanders focus sites in the Red River Valley. Excluding the collections from the Hines, Spoonbill and Taddlock sites ${ }^{22}$-- where Bruseth and Perttula (1981:77) admittedly ${ }^{23}$ used a non-standard form of ceramic classification that disregards temper, design placement and style of design, all critical attributes in the identification of Sanders Engraved -only 78 sherds $^{24}$ of this type are reported from the remaining 20 Red River Valley 
Volume 7, Number 4

sites that supposedly have Sanders focus components. Even if all of these sherds were positively from real Sanders Engraved pots, which I doubt, this type would be too meagerly represented to support the concept of a regional Sanders focus or phase. Like the Maxey Noded Redware sherds, the few real sherds of Sanders Engraved that may be among these 76 are best accounted for as the remains of Sanders Engraved pots from the Arkansas Valley that local Caddos obtained in trade from the Sanders entrepot.

The figures for Sanders Plain at Red River Valley sites would seem to suggest that this type, at least, may have been fairly well represented. But they are inflated as a result of systematic errors in the classification of Sanders Plain that regional archeologists have been making throughout the last fifty years. When corrected to compensate for these errors, the figures for the relative and absolute representation of this type also decrease practically to the vanishing point at almost all sites.

The main reason for the misclassification of Sanders Plain is that, as Brown $(1971: 167-169 ; 1996: 402)$ has pointed out, Krieger erred initially by defining the type so broadly that it included not only red slipped pottery but Williams Plain, the unslipped Fourche Maline type that is ubiquitous in the Red River Valley (Schambach 1982:132-197). This error was codified in successive editions of the Handbook of Texas Archaeology (Suhm, Krieger and Jelks 1954; Suhm and Jelks
1962:139) wherein Sanders Plain is described, with astounding ambiguity, as a "clay-grit" or clay-grit and pulverized bone-tempered bowl, bottle and jar type in which "Baked red film occurs on perhaps 15 percent of the vessels, primarily bowls". This was an open invitation for regional archeologists to misclassify whole collections of plain grog or grog and bone tempered sherds as Sanders Plain, particularly if they happened to include small numbers of red slipped sherds (Table 2, the Beaver, E, Johnson and Payne collections), but sometimes even if they did not (Table 2, the Kaufman and Yarbrough collections). This option remained open until Brown (1971:164-169) pointed out that most of the unslipped plain pottery from the middens at Sanders ${ }^{25}$ (and, obviously, most of the pottery from other local sites identified up to that time as Sanders Plain) is probably Williams Plain.

Unfortunately, Brown's reclassification of Sanders Plain to exclude Williams Plain did not put an end to the problems with the identification of this type. For two reasons, it continues to be misidentified and, when that happens, continues to provide spurious support for the Sanders focus concept. One source of error is that when Brown (1971:164-165) redefined Sanders Plain to distinguish it from Williams Plain he redefined it, not as a red slipped type (as any archeologist trained in the Lower Mississippi Valley Survey school of ceramic taxonomy would have done automatically; Phillips, Ford and Griffin 1951; Phillips 1970) but simply as a "slipped" type. Thus he made it all but 
Table 2.

\begin{tabular}{|c|c|c|c|c|}
\hline Sites & $\begin{array}{c}\text { Total } \\
\text { "Sanders } \\
\text { Plain" } \\
\end{array}$ & $\begin{array}{l}\text { Total } \\
\text { Rims }\end{array}$ & Red-sHipped & Reference \\
\hline A. Mackin & 28 & unspecified & all - 1 or both surfaces & Mallouf 1976:292 \\
\hline Baldwin & 39 & 7 & "usually" some buff & Rohrbaugh 1968:11 \\
\hline Beaver & 818 & unspecified & 180 red-slipped, both sides & Wyckoff 1968:11 \\
\hline Bell & 10 & 1 & yes, both sides & Wyckoff 1968:76 \\
\hline Clement & - & - & - & Bell and Baerreis 1951 \\
\hline Cook & - & - & - & Bell and Baerreis 1951 \\
\hline E. Johnson & 301 & 41 & red, buff or brown slip & Wyckoff 1967:128-130 \\
\hline Fasken & - & - & $=$ & Prikryl 1991, 1992 \\
\hline Gregory & 15 & 1 & all on exterior; 4 on interior also & Wyckoff 1968:141 \\
\hline Harling & - & - & - & Davis $1962 a, 1962 b$ \\
\hline Hines & - & - & - & Bruseth and Pertula 1991 \\
\hline Holdeman & - & - & - & Perino n.d. \\
\hline Kauafman & 29 & 29 & "all unslipped" & $\begin{array}{l}\text { Skinner et al. 1968:47, } \\
\text { Tables } 5,6\end{array}$ \\
\hline Mahaffey & 13 & 13 & unspecified & Perino and Bennett 1978 \\
\hline Nelson & 79 & 23 & $\begin{array}{l}\text { red slipped } 61 \text {, gray slipped } 5 \text {, } \\
\text { unspecified slipped } 13\end{array}$ & Rohrbaugh 1973:187-188 \\
\hline Pat Boyd & 252 & 38 & $\mathrm{red} / \mathrm{red}$ brown & Rohrbaugh 1973:80 \\
\hline Payne & 532 & 47 & 119 red slipped, 191 gray slipped & Rohrbaugh 1973:6 \\
\hline Pine Creek & 10 & unspecified & various colors, except red & Gettys 1975:159 \\
\hline Spoonbill & - & - & - & Bruseth and Pertula 1981 \\
\hline Taddlock & - & - & - & Bruseth and Perttula 1981 \\
\hline T. Moody & - & - & - & Perttula et al. 1988 \\
\hline Woods Mound & - & - & - & Wyckoff 1967a \\
\hline Yarbrough & 89 & 52 & - & Johnson 1962:230 \\
\hline TOTAL & 2215 & 211 & & \\
\hline
\end{tabular}


Volume 7, Number 4

impossib's to sort, in sherd form, from plain sherds of any other type that happens to be slipped. Since much of the grogtempered late Fourche Maline pottery and most Caddo pottery in the Red River Valley is slipped in various shades of brown or gray ${ }^{26}$ the possibilities for error that this move opened are almost limitless. Although some published identifications of Sanders Plain (Table 2, the Mackin, Bell and Gregory collections) are restricted to red slipped sherds, an indication I am not alone in thinking Brown was wrong on this point, others -- obviously -- are not and are suspect accordingly. Predictably, the largest reported collections of Sanders Plain are those that include sherds with slips of various colors rather than just red (Table 2; the Beaver, E. Johnson, Nelson, Pat Boyd and Payne collections). Pending reanalysis, the value of these collections as markers for Sanders phase occupations is low, particularly when, as is usually the case, they are from sites yielding few or no other supposed "Sanders focus" diagnostics.

The other source of error in sorting this type, whether it is defined as slipped or red slipped, is that many archeologists have been ignoring, or are ignorant of, the following inescapable operational fact pertaining to the classification of Red River Valley pottery. Because the Red River Valley abounds with slipped types of various colors -- particularly red -- that have decorated rims or upper bodies but plain bodies and bases, plain slipped body sherds of any color are not sortable to type. Thus some reports fail to specify how many of the sherds classified as
Sanders Plain are rim sherds and how many are body sherds (Table 2, the A. C. Mackin, Beaver and Pine Creek collections) thereby rendering the classification invalid. Others do specify (Table 2, the Baldwin, Bell, E. Johnson, Gregory, Nelson, Pat Boyd, and Payne collections), thus making it clear that in these cases most of the sherds classified as Sanders Plain are not rim sherds, which are classifiable in the case of Sanders Plain, but body sherds, which are not. If the raw data on so-called Sanders Plain pottery in the Red River Valley (Table 2) are "corrected" to (1) remove all unslipped sherds and (2) to show what would probably happen if the remainder were restudied and reclassified in ways that would compensate for the taxonomic and operational errors that are inherent in the process of sorting Sanders Plain as that type is presently defined and understood, the quantity of Sanders Plain decreases dramatically. Eliminating as unsortable to type all sherds that are probably body sherds reduces the total of 2215 reported sherds to 211 , the number of reported rim sherds. Subtracting from that the 29 unslipped rim sherds from the Kaufman site, the 52 unslipped rim sherds from the Yarbrough site, and (to be a stickler for detail, as one must when it comes to ceramic classification) the 13 rims with unspecified surface treatment from the Mahaffey site, leaves but 117 sherds that stand a reasonably good chance of being Sanders Plain.

I am sure there are those who will wish to argue that this figure is unrealistically small. But before they do I suggest they consider the implications of the fact that 
no Sanders Plain pottery is reported (Table 1) in the three largest and most carefully described collections from alleged Sanders focus sites in the Red River Valley, those from the recently studied (Bruseth and Perttula 1981) Hines, Spoonbill and Taddlock sites. In any case, I consider this figure (117 sherds) a realistic representation of the distribution of real Sanders Plain pottery at Red River Valley sites. As -- I think -- is the case with the proportionately small corrected figures for the distribution of Maxey Noded Redware and Sanders Engraved in the Red River Valley, it probably reflects the fact that a small number of traded pots of Sanders Plain were in circulation due to the activities of the Spiroans at the Sanders entrepot.

What of Brooks's (1996:21) vague and speculative assertion that "the red slipped pottery of the Spiro phase is somehow linked to the development of these wares within sites related to the Sanders focus"? I think it is belied by comparison of the facts and figures on the actual, as opposed to the supposed, distribution of red slipped "Sanders focus" pottery types in the Red River Valley with those on the distribution of red slipped pottery in the Arkansas Valley. Pottery classified as Sanders Plain is better represented in the collections from Spiro alone, 26 pots and 2,339 sherds (Brown 1971:164-169; 207,Table 44), than it would be at all alleged Sanders focus sites in the Red River Valley even if every reported occurrence of this type were accepted at face value, which would amount to 2215 sherds and nine pots. And it appears to have been abundant else- where in the Arkansas Valley in eastern Oklahoma where, according to Brown (1996:403), it was "distributed extensively ... during the Norman and Spiro phases" ${ }^{17}$. Furthermore, neither Brooks nor anyone else (see Bruseth, Wilson and Perttula 1995:226) still arguing that Sanders Plain is a Red River Valley type can point to a plausible Red River Valley parent type for it now that Brown (1971:167-169; 1996:402) has severed the old, false connection between Williams Plain and Sanders Plain. But both Sanders Plain and Sanders Engraved are, as I have argued elsewhere (Schambach 1993:212-213) easily derived from the Mississippi Valley type Old Town Red which Brown (1996:404; Brown 1971:180) describes as "not distinguishable in paste or surface treatment from Sanders Plain", the only difference between these taxa being the rounded bases on Old Town Red pots. This type is, according to Brown, represented at Spiro by "10 complete bowls and 15 basal bowl sherds" (Brown 1996:404). These figures might suggest that Old Town Red is too weakly represented at Spiro to be taken seriously as the parent type for Sanders Plain but they are simply an artifact of Brown's faulty classification of Sanders Plain as a type that is sortable from Old Town Red on the basis of only one attribute, base form. Hence, as Brown (1996:404) admits, all rim sherds and body sherds of Old Town Red from Spiro are "included among the Sanders Plain sample". In other words, then, there is no telling how many of 2,339 sherds from Spiro that are classified as Sanders Plain are actually Old Town Red, but it is a good bet that a 
significant number of them are. There is no telling either, how much of the so-called Sanders Plain pottery that, according to Brown (1996:403), was "distributed extensively" in the Arkansas Valley "during the Norman and Spiro phases" is also Old Town Red, but -- again -- it is a good bet that some of it is. Thus I see no reason to alter my opinion that the so-called Sanders Plain pottery from the Sanders site, and the small numbers of sherds and pots of the same pottery that can be identified at other Red River Valley sites belongs to an as yet unnamed Arkansas Valley variety of Old Town Red -- it should probably be called Old Town Red var. Sanders-- that was imported by Spiroan traders.

The fourth aspect of my new paradigm for the culture history of the Arkansas Valley with which Brooks takes issue is my hypothesis that the Spiroans amassed the wealth they eventually buried in the Craig Mound through long distance trading in scarce commodities, particularly Osage orange bows and buffalo products, collected at strategically located entrepots such as the Sanders site in northeast Texas and the Nagle site in central Oklahoma. His major objection to this hypothesis is based on the fact that he has conflated the concept of entrepots with the quite different concept of "ports of trade". I agree that the Southeastern polities of the Mississippi period probably were not sophisticated enough to have developed "ports of trade," which (according to Polanyi:1963:30-31) were essentially neutral zones, either in coastal areas or inland at the borders between diverse ecological regions, that were established and maintained for the purpose of conducting trade of a generalized nature between early states. But I never suggested that the Mississippians were maintaining ports of trade. As I envision them (and since this is my hypothesis, it is my conceptualization that counts, not Brooks's) the numerous entrepots like the Sanders site and the Nagle site that, I suspect, were in operation around the periphery of the Mississippian heartland were not primarily centers, neutral or otherwise, for commerce of a general nature. They were -- to paraphrase the definition of the term entrepot which is to be found in Webster's Third International, Unabridged -- places serving as centers for the collection of particular commodities that were of value to the Mississippians. Thus I think the Sanders entrepot was established and maintained, not for the purpose of trade in all and sundry with the local population, which -in the immediate area of the Sanders site -would have been minuscule, but for the collection of bows or bow staves of Osage orange (Maclura pomifera), a commodity of great value because of its superiority as a bow wood and its phenomenal scarcity. Evidently it could only be found in a small area around the Sanders site (Schambach 1995: 12-13) and that was main reason for the location of the site. Similarly, the entrepot at Nagle was established, as I have argued elsewhere (Schambach 1995:19-20), precisely at the point where Spiroan traders traveling west up the North Canadian River would have found the first local populations of Plains hunters capable of supplying them with buffalo products in quantity, probably in exchange 
for Osage orange bows, among other things.

Brooks (1996:22) also contends that my model is inappropriate because "Complex chiefdoms such as we find in the southeast ... never relied on maintenance of a permanent settlement in the foreign territory" for trade. That is more or less the conventional view on this matter. But I contend that the data from Sanders and Nagle constitute strong circumstantial evidence that it is wrong, that entrepots (I wouldn't go so far as to call them "permanent settlements" ${ }^{128}$ ) were maintained at numerous points around the periphery of the Mississippian heartland. And I see no compelling theoretical reason why this could not have been the case. My position on the interpretation of data pertaining to the nature and activities of the various Mississippian societies is that, within fairly broad theoretical limits, we can only assume that the Mississippians did what they did and make it our business as archeologists to find out what that was without being overly constrained by the limited historical, ethnographic and theoretical literature on the activities and capabilities of chiefdoms world-wide. I suspect that if we were guided by the ethnographic and historical literature alone with respect to the capabilities of the Mississippian chiefdoms we might have to give up the idea that they built ceremonial centers on the scale of Cahokia, Moundville and Etowah.

As it happens, the view -- accepted as Gospel by Brooks, among others -- that Spiro was organized as a chiefdom has recently been questioned by Brown (1996:198) as being too simplistic. In a lengthy comment that indirectly (but, I am sure, unintentionally) strengthens my argument that Spiro was not a normal Southeastern chiefdom but a settlement of entrepreneurs supporting themselves and amassing wealth through long-distance trade, he states as follows: "The view that Spiro owed its wealth to the institutional benefits of a locally based chiefdom has been central to all recent discussion of Southeastern political economy. At Spiro the concentration of widely distributed wealth items conforms to the theoretical expectations of a system in which a strategically situated elite have a decided advantage in manipulating the flows of exchange or in controlling the means of production, or access to scarce resources. However this interpretation of Spiro wealth has to be tempered by the empirical evidence that the period of concentration predated by centuries the onset of social complexity associated with political chiefship in the Southeast. A different line of reasoning has to be evoked to explain the Spiroan political economy at various points in time." Naturally, I agree, since I have offered a different line of reasoning.

A key element in my interpretation of the Sanders and Nagle sites as entrepots is, of course, that both sites were occupied by small groups of people, Spiroans in my opinion, who differed culturally and physically from the local peoples. Brooks agrees that the people buried at Nagle were foreigners, probably Spiroans, and, in fact, there has never been much question about this (Shaeffer 1957:97-98; Griffin 
Volume 7, Number 4

1961:30). But he prefers his ad hoc explanation for their presence at a Plains site 170 miles west of Spiro in central Oklahoma. It is that "the Nagle people were a refugee population from the Spiro site .... a lineage or population group that was forced to emigrate" (Brooks 1994: 319-321). This explanation is rudimentary, at best, since Brooks does not say what event or situation he thinks his Spiroan refugees were fleeing and his explanation for why, rather than taking refuge with kinsmen elsewhere in the Arkansas Valley in eastern Oklahoma or western Arkansas in territory that would have been familiar to them, they fled west into the Plains where they perished as strangers in a strange land, is extraordinarily vague and weak. It is that "it is well documented that relations between Caddoan groups were often strained" (Brooks 1996:23).

Undaunted by these problems, Brooks presents three reasons for preferring his interpretation of the Nagle site to mine. The "First and foremost" of these is that "there is no evidence of a settlement at this location [i.e., at the Nagle site] or in the immediate vicinity". In the next sentence he makes clear that when he refers to a settlement he means "a village." I am not troubled by this because I would expect the remains of an entrepot, occupied perhaps only seasonally and perhaps only for a few years by a small group of traders, to be considerably less obvious than the remains of a village-sized settlement. Such remains -- which may well be silted under, judging from Shaeffer's (1957:93) description of the Nagle site as being located "on the south bank of the North
Canadian River" -- could easily have been missed since the area excavated was very small (about 15 feet by 15 feet according to Shaeffer 1957: Plate 22) and the work consisted mainly of removing the graves in the small cemetery that was exposed during a pipeline construction project. In any case, I do not see why Brooks thinks the fact that habitation debris has not been discovered at the Nagle site favors his hypothesis over mine. Does he think that some 20 of his "refugees" just happened to die in transit at this location, where they were hastily buried by the survivors or by Good Samaritans of some group of Plains people? Or does he think they were brought to Nagle (why and by whom?) for burial in an isolated cemetery after having died elsewhere? Since the normal burial pattern in the Arkansas Valley homeland of these people involved interment in small cemetery plots located near the houses the deceased occupied in life, and since the area excavated at Nagle (225 square feet) was not large enough to prove that there was no habitation, I consider the graves themselves evidence that there was a habitation area -- the remains of a Spiroan entrepot -- nearby.

The second reason Brooks prefers his interpretation of the Nagle site to mine is that nine of the 20 people represented by the skeletal remains were infants and children, none more than 10 years old (Brues 1957:101), and he thinks it "highly unlikely that a 'Port of Trade' would include infants and young children". That, of course, is a spurious objection since I did not, and do not, interpret Nagle as a "Port of Trade". That is his idea. The 
question is, would children have been present at an entrepot? Obviously, I see nothing wrong with that because the skeletal remains of children (nine of them) were also found at the Sanders site (Schambach 1993:204). Since the populations of both sites seem to have included both males and females, the presence of children as well would be just about inevitable, whether or not their presence was conducive to the efficient operation of an entrepot. And it could have been beneficial in maintaining amicable relations with local groups if any of them happened to be the offspring of Spiroan men and local women ${ }^{29}$. In any case, the large number of subadults in the cemetery at Nagle indicates, according to Brues (1957:103), that conditions there were not good for children and the mortality rate among them was extremely high, a circumstance that does not contradict my interpretation of the site. It does not mean, as Brooks (1996:23) -- if I read him right on this -- concludes, that half of the living Nagle site population was "under 15 years of age," a condition he considers "highly suspect for a group of traders".

The third reason Brooks prefers his interpretation of Nagle to mine is that the Nagle site population was, according to Brues (1957:103), clearly suffering from "malnutrition", something he thinks the local population would not have allowed to happen to traders with whom they were on good terms. However, the dietary deficiency disorder from which these people were suffering was, in Brues' opinion (1957:103-104), not outright starvation but scurvy, which "would ... have arisen after a winter of reliance on comfortable supplies of corn and beans". Most likely neither the etiology nor the cure for this disorder would have been apparent to the victims or to Brooks's putative caring hosts since Brues suggests it was probably the result of some "apparently minor" dietary error such as "eating liver cooked rather than raw" or "eliminating squash from the roster of cultivated plants". All of this is consistent with my hypothesis that the Nagle site was an entrepot peopled by Spiroan traders: they were apparently well-fed but they -the children particularly -- suffered from the kind of dietary mistakes I would expect an immigrant population from the Eastern Woodlands to the Plains to make. Because scurvy takes months to develop and it is generally a disorder of the winter months when fresh vegetable foods and fruits are unavailable, it is apparent that they wintered on the Plains, probably at the Nagle site or in the vicinity, since that is where their dead accumulated. While it is possible that the small cemetery at Nagle contains the dead of just one winter, it is just as possible that most of the adults, at least, and some of the children, survived the scurvy each year and that the dead of more than one winter were interred there. Assuming the population which established the entrepot included no children initially, the fact that the cemetery contains adults over twenty and infants and children of all ages up to age 10 , but no teenagers, suggests that the entrepot was in operation for about 10 years.

My reinterpretation of the Spiro site as a base for long-distance traders is heavily, although not entirely, dependent on my 
Volume 7, Number 4

argument that the sites of not one, but two strategically located Spiroan entrepots can be identified from the existing literature: the Nagle site and the Sanders site. Brooks does not discuss Sanders in his paper, claiming (1996:22) that "the issue of Sanders and its importance as a trade center has been dealt with by Bruseth, Wilson and Perttula (1995)". But if by "dealt with" he means effectively challenged in any respect, or even refuted, either of which would support his argument, he is wrong. As I pointed out in a paper presented at the last Caddo Conference (Schambach 1996), Bruseth, Wilson and Perttula's case against my hypothesis, which hinges on the argument that the occupants of the Sanders site were not immigrants from Spiro -- as the cultural and bioanthropological evidence indicates just as clearly as it does at Nagle -- but people belonging to a local Red River Valley Caddo population represented by twenty-three so-called Sanders focus/phase sites $^{30}$ in northeast Texas and southeast Oklahoma, has recently collapsed. The cause of its collapse is a pair of papers (Derrick and Wilson 1995; Wilson and Derrick 1996) which bring to light conclusive bioanthropological evidence that the people interred in the cemetery at the Sanders site were immigrants from the Arkansas Valley, as the cultural evidence so strongly indicates. These papers also support my basic hypothesis that the Mississippi period population of the Arkansas Valley was significantly different, biologically and culturally, from the Caddo populations living south of the Ouachita Mountains in the Red River Valley and elsewhere. Wilson and Derrick's crucial discovery, made in the course of a survey of the styles of "cranial modeling" -- the term they prefer for head deformation -exhibited by all skulls from presumed "Caddo" contexts in east Texas (Derrick and Wilson 1995), was that two distinct styles of "modeling", produced by different techniques, are represented in skulls from that area. There is a "tabular" style (Figure 1) which was obviously the norm for the Caddo throughout east Texas and (as Wilson has recently informed me) southwest Arkansas, since it is the only one represented in significant numbers at all but two sites, Sanders and the nearby Womack $^{31}$ site. This is not surprising since the tabular style, usually loosely called the "frontal-occipital style," prevails throughout most of the Southeast. But at Sanders and Womack only (in the Red River Valley) a readily distinguishable "annular" style (Figure 1), a style also characteristic of the males buried at the Nagle site (Brues 1957:107), prevails. Although it originally appeared to be a Red River Valley style because the first good examples reported for eastern North America came from the Sanders site (Goldstein 1940; Stewart 1941:350), subsequent work by Brues indicates that its real homeland is the Arkansas Valley in eastern Oklahoma. There, and apparently only there, it is well represented in every significant population of Mississippi period skeletons that has been studied by bioanthropologists. It is "almost universal" in the Horton site population of 33 individuals (Brues 1958:32); it is recognizable in seven of 55 individuals from the Morris site (Brues 1959:69) and 
it appears (to me) to be represented in three of the seven skulls from the Craig mound at the Spiro site that survived more or less intact (Brown 1996: Figure 2-8, a, and Figure 2-10, a and e). There is also iconographic evidence that it was a Spiroan style. Most of the human heads depicted in the shell art from Spiro (Phillips and Brown 1978) are shown in profile, making it impossible to tell whether the cranial deformation that is obvious in many cases was annular or frontal-occipital. But the few that are shown full face (Phillips and Brown 1978:Figure 7, specimens 216, 281 and 283) appear to be depictions of people with annular deformation because of the decidedly abnormal way the heads narrow from the ears up. Perhaps not coincidentally, all of these belong to the "Craig school" of Mississippian shell art, the one such school that Phillips and Brown consider indigenous to Spiro.

There is also historical evidence that annular cranial deformation was still being practiced by people living in the Arkansas Valley in eastern Oklahoma or extreme western Arkansas in 1541. In that year, in the province of "Tula" located -- there is now little doubt -- somewhere in the Fort Smith/Spiro area (Early 1993:74-75; Hudson 1993:146-147), Spaniards of the De Soto expedition encountered people exhibiting cranial deformation described as follows by Garcilaso (Varner and Varner 1951:457-458). "Their heads are incredibly long and taper off towards the top having been made this way by artifice; for from the moment they are born their heads are bound and are left thus until they are from nine to ten years of age." This is a perfect description of annular style of cranial modeling, which makes the subject's head look very long, seen from the front or the side, and -- particularly -- makes it "taper off towards the top" when seen from the front, rather than bulging above the ears as is the case with frontal-occipital deformation. Garcilaso (Varner and Varner 1951:457-458) also gives a plausible description of how annular deformation was accomplished. Instead of binding the infant to a cradle board every night for the first two years or so of life, as seems to have been the custom almost universally in the Southeast (Swanton 1946:539 ff.) the people of Tula wrapped their children's heads with broad bands of cloth or leather which they wore more or less constantly until they were 8 or 9 .

Thus the annular style of cranial deformation appears to have been characteristic of and unique to the population of the Arkansas Valley in eastern Oklahoma from about A.D. 1100 through 1541. Where it is identified outside that area, in contexts such as those at Nagle and Sanders that also contain assemblages of Spiroan artifacts, it can be considered proof of the presence of Spiroan peoples. I suspect that its function, if not its original purpose, was similar. People throughout the far-flung sphere of operation of the Spiroan traders would have recognized the Spiroans for who and what they were by the distinctive shape of their heads.

Let me summarize the main points I have tried to make in this paper. Brooks objects 
to my generalizations that the Mississippi period people of the Arkansas Valley, whom I call the Spiroans, were distinct culturally and bioanthropologically from the Caddo to the south and that they were long-distance traders who operated a system of entrepots which included the Nagle site in central Oklahoma and the Sanders site in northeast Texas. Two of his most important objections are groundless because they are based on his own elementary misunderstandings of the data and concepts employed in my argument. $\mathrm{He}$ is ignorant of the nature and etiology of endemic syphilis, which he mistakes for a venereal disease, and he has unaccountably conflated the concept of "ports of trade," an institution characteristic of early states, with the concept of entrepots, an institution that I think would be appropriate for societies at the level of organization of the Mississippian societies of the Southeast. The rest of his objections, large and small, are based not on the data, much of which are evidently unfamiliar to him, but on faith in the old paradigm. He believes that if he troubled to read the basic literature on the archeology of the Arkansas Valley and the Red River Valley he would find the facts which are supposed to support the traditional interpretation of the Mississippi period archeology of the Arkansas Valley and of the Sanders and Nagle sites as manifestations of Caddo culture. But, as I trust I have shown in sufficient detail, that faith is misplaced. The cultural and bioanthropological data, much of it recently accumulated, not only do not support the old paradigm, they contradict it at every turn. Nor do they support the ad hoc constructs Brooks has devised in a futile attempt to prop up various elements of the old paradigm.

\section{ACKNOWLEDGMENTS}

I thank Tom Green, David Jeane, Marvin Jeter, David Kelley and Robert Mainfort for their prompt and helpful comments on earlier drafts of this paper.

\section{REFERENCES CITED}

Bell, Robert E., and David A. Baerreis

1951 A Survey of Oklahoma Archaeology. Bulletin of the Texas Archeological and Paleontological Society 22:7-100.

Brooks, Robert L.

1994 Warfare on the Southern Plains. In Skeletal Biology in the Great Plains: Migration, Warfare, Health, and Subsistence, edited by Douglas W.
Owsley and Richard L. Jantz, pp. 307-323. Smithsonian Institution Press, Washington and London.

1996 The Arkansas Valley: A New Paradigm, Revisionist Perspectives and the Archeological Record. Caddoan Archeology 7(1): 17-27.

Brown, James A.

1971 Spiro Studies, Volume 3. Pottery 
Vessels. Stovall Museum of Science and History, and University of Oklahoma Research Institute, Norman.

1984 Arkansas Valley Caddoan: The Spiro Phase. In Prehistory of Oklahoma, edited by Robert E. Bell, pp. 241-263. Academic Press, Orlando.

1996 The Spiro Ceremonial Center: The Archaeology of Arkansas Valley Caddoan Culture in Eastern Oklahoma, Volumes 1 and 2. Memoirs of the Museum of Anthropology No. 29. University of Michigan, , Ann Arbor.

Brues, Alice M.

1957 Skeletal Material from the Nagle Site. Bulletin of the Oklahoma Anthropological Society 5:101-106.

1958 Skeletal Material from the Horton Site. Bulletin of the Oklahoma Anthropological Society 6:27-32.

1959 Skeletal Material from the Morris Site, Cd-39. Bulletin of the Oklahoma Anthropological Society 7:63-70.

1962 Skeletal Material from the McLemore Site. Bulletin of the Oklahoma Anthropological Society 10:68-78.

Bruseth, James E. and Timothy K. Perttula 1981 Prehistoric Settlement Patterns at Lake Fork Reservoir. Texas Antiquities Permit Series Report 2. Texas Historical Commission, Austin.
Bruseth, James E., Diane E. Wilson and Timothy K. Perttula

1995 The Sanders Site; A Spiroan Entrepot in Texas? Plains Anthropologist 40 (153):223-236.

Burnett, Barbara A.

1988 The Biological Synthesis. In Human Adaptation in the Ozark and Ouachita Mountains, edited by George Sabo III, Ann M. Early, Jerome C. Rose, Barbara A. Burnett, Louis Vogel, Jr. and James P. Harcourt, pp. 193-220. Research Series No. 31. Arkansas Archeological Survey, Fayetteville.

Davis, E. Mott

1962a Archaeological Salvage Investigations of the Harling Mound in Fannin County, Texas. American Philosophical Society Year Book 1961: 487-489.

1962b The Harling Site (41Fn1) Fannin County, Texas. Plains Anthropologist $7(16): 86$.

Derrick, Sharon McCormick, and Diane E Wilson

1995 Cranial Modeling As An Ethnic Marker Among the Prehistoric Caddo. Unpublished paper cited with permission of the authors.

Duffield, Lathel F.

1969 The Vertebrate Faunal Remains from the School Land 1 and School Land II Sites, Delaware County, Oklahoma. Oklahoma Anthropological Society Bulletin 18:47-65. 
Volume 7, Number 4

Dow, Laura Ann Brantly

1987 The Genetic Affinities and Adaptive Success of Three Groups of Late Prehistoric Amerindians From Texas. Master's Thesis, Department of Anthropology, University of Texas, Austin.

Early, Ann M.

1993 Finding the Middle Passage: The Spanish Journey from the Swamplands to Caddo Country. In The Hernando de Soto Expedition West of the Mississippi, 1541-1543, edited by Gloria A. Young and Michael P. Hoffman, pp. 68-77. University of Arkansas Press, Fayetteville

Finklestein, Joe J.

1940 The Norman Site Excavations Near Wagoner, Oklahoma. The Oklahoma Prehistorian 3(3):12-15.

Flynn, P.

1976 A Study of Red-Filmed Pottery from the Clement Site (Mc-8), McCurtain County, Oklahoma. Bulletin of the Oklahoma Anthropological Society 25:127-134.

Fritz, Gayle J.

1989 Evidence of Plant Use from Copple Mound at the Spiro Site. In Contributions to Spiro Archaeology: Mound Excavations and Regional Perspectives, edited by J. Daniel Rogers, Don G. Wyckoff and Dennis A. Peterson, pp. 65-87. Studies in Oklahoma's Past No. 16. Oklahoma Archeological Survey, Norman.
Gettys, M

1975 Preliminary Report on Archaeological Investigations at Lufkata Reservoir, Southeastern Oklahoma. General Survey Report No. 14, Oklahoma River Basin Survey, University of Oklahoma, Norman.

Goldstein, M. S

1940 Cranial Deformation Among Texas Indians. American Journal of Physical Anthropology 27:312-313.

Grieco, Michael H.

1995 The Voyage of Columbus Led to the Spread of Syphilis to Europe. In Columbus and the New World: Medical Implications, edited by Guy A. Settipane, M.D., pp. 29-31. OceanSide Publications, Inc., Providence.

Griffin, James B.

1961 Relationships Between the Caddoan Area and the Mississippi Valley. Bulletin of the Texas Archeological Society 31:27-43.

Hackett, C. J.

1963 On the Origin of the Human Treponematoses. Bulletin WHO 29:7-41

Harris, R. K 1953 The Sam Kaufman Site, Red River County, Texas. Bulletin of the Texas Archeological Society 24:43-68.

Harmon, Anna M. and Jerome C. Rose 1989 Bioarcheology of the Louisiana and Arkansas Study Area. In Archeology 
and Bioarcheology of the Lower Mississippi Valley and the Trans Mississippi South in Arkansas and Louisiana, by Marvin D. Jeter, Jerome C. Rose, Ishmael Williams, Jr., and Anna M. Harmon, pp. 323-354. Research Series No. 37. Arkansas Archeological Survey, Fayetteville.

\section{Hudson, Charles}

1993 Reconstructing the de Soto Expedition Route West of the Mississippi River: Summary and Contents." In The Hernando de Soto Expedition West of the Mississippi, 1541-1543, edited by Gloria A. Young and Michael P. Hoffman ,pp. 143-154. University of Arkansas Press, Fayetteville.

Jeter, Marvin D., Jerome C. Rose, Ishmael Williams, Jr., and Anna M. Harmon 1989 Archeology and Bioarcheology of the Lower Mississippi Valley and the Trans Mississippi South in Arkansas and Louisiana. Research Series No. 37. Arkansas Archeological Survey, Fayetteville.

Johnson, L., Jr.

1962 The Yarbrough and Miller Sites of Northeastern Texas, with a Preliminary Definition of the La Harpe Aspect. Bulletin of the Texas Archeological Society 32:141-284.

Krieger, Alex D.

1946 Culture Complexes and Chronology in Northern Texas, with Extensions of Puebloan Datings to the Mississippi Valley. Publication 4640. The University of Texas, Austin.
Little, Elizabeth A.

1987 Inland Waterways in the Northeast. Midcontinental Journal of Archaeology 12:55-76.

Mallouf, R. J.

1976 Archeological Investigations at Proposed Big Pine Lake, 1974-1975: Lamar and Red River Counties, Texas. Archeological Survey Report 18. Texas Historical Commission, Austin.

Martin, W. A.

1991 Roitsch Site (formerly Sam Kaufman site). Texas Archaeology 35(3):8-9.

1992 The Roitsch Site (4RR16). Texas Archeology 36(3):8-10.

Neumann; Georg K.

1942 Types of Artificial Cranial Deformation in the Eastern United States. American Antiquity 3:306-310.

Owsley, Douglas, and Richard L. Jantz 1989 A Systematic Approach to the Skeletal Biology of Southern Plains. In From Clovis to Comanchero: Archeological Overview of the Southern Great Plains, by Joe S. Hays, Douglas W. Owsley, Richard L. Jantz, Murray K. Marks, and Mary H. Manhein, pp. 137-156. Research Series No. 35. Arkansas Archeological Survey, Fayetteville.

Phillips, Philip

1970 Archaeological Survey in the Lower Yazoo Basin, Mississippi, 1949-1955. Papers of the Peabody 
Volume 7, Number 4

Museum of Archaeology and Ethnology, Vol. 60. Harvard University, Cambridge.

Phillips, Philip and James A. Brown

1978 Pre-Columbian Shell Engravings from the Craig Mound at Spiro, Oklahoma [Paperback Edition, Part 1]. Peabody Museum of Archaeology and Ethnology 60. Harvard University, Cambridge.

Phillips, Philip, James A. Ford, and James B. Griffin

1951 Archaeological Survey in the Lower Mississippi Alluvial Valley, 1940-1947. Papers of the Peabody Museum of American Archaeology and Ethnology, Vol. 25. Harvard University, Cambridge.

Perino, G.

n.d. Holdeman Site Report. Manuscript on file at the Museum of the Red River, Idabel, Oklahoma.

Perino, G and W. J. Bennett, Jr.

1978 Archaeological Investigations at the Mahaffey Site, Ch-1, Hugo Reservoir, Choctow County, Oklahoma. Museum of the Red River, Idabel.

Perttula, T. K., K. Gilmore, P. McGuff, and B. D. Skiles

1988 Archaeological Survey and Testing along Mill Race Creek and Tributaries, Wood County, Texas. Texas Archeology 32(1):7-8.
Polanyi, Karl

1963 Ports of Trade in Early Societies.

The Journal of Economic History 23:30-45.

Prikryl, D. J.

1991 Fasken Mounds. Texas Archeology 35(3): 1-6.

1992 Fasken Mounds. Texas Archeology 36(3):10-12.

Rohrbaugh, Charles L.

1968 The W. H. Baldwin Site, McCurtain County, Southeast Oklahoma. Miscellaneous Report No. 3. Oklahoma River Basin Survey, University of Oklahoma, Norman.

1973 Hugo Reservoir III: A Report on the Early Formative Cultural Manifestations in Hugo Reservoir and in the Caddoan Area. Archaeological Site Report No. 24. Oklahoma River Basin Survey, Norman.

1982 'Spiro and Fort Coffee Phases: Changing Cultural Complexes of the Caddoan Area. Ph.D. dissertation, University of Wisconsin-Madison. University Microfilms, Ann Arbor.

Rohrbaugh, C. L., R. J. Burton, S.S. Burton, and L. J. Rosewitz

1971 Hugo Reservoir I: The Description of the Archaeological Sites Excavated During the 1970 Field Season, Including Ch-1, Ch-43, Ch-70, Ch-75, $\mathrm{Pu}-82$, and Ch-90. Archaeological Site 
Report No. 22. Oklahoma River Basin Survey, University of Oklahoma, Norman.

\section{Rogers, J. Daniel}

1996 Markers of Social Integration: The Development of Centralized Authority in the Spiro Region. In Political Structure and Change in the Prehistoric Southeastern United States, edited by John F. Scarry, pp. 53-68. University Press of Florida, Gainesville.

Rothschild, Bruce M., and Christine Rothschild

1996 Treponemal Disease in the New World. Current Anthropology 37(3):555-561.

Schambach, Frank F.

1982 An Outline of Fourche Maline Culture in Southwest Arkansas. In Arkansas Archeology in Review, edited by Neal J. Trubowitz and Marvin D. Jeter, pp. 132-197. Research Series No. 15. Arkansas Archeological Survey, Fayetteville.

1993 Some New Interpretations of Spiroan Culture History. In Archaeology of Eastern North America; Papers in Honor of Stephen Williams, edited by James B. Stoltman, pp. 187-230. Archaeological Report No. 25. Mississippi Department of Archives and History, Jacksonville.

1995 A Probable Spiroan Entrepot in the Red River Valley in Northeast Texas. Caddoan Archeology Newsletter 6(1):10-25.
1996 The Womack, Gilbert and Pearson Sites; Early Eighteenth Century Tunican Entrepots in Northeast Texas? A Paper Presented at the 38th Caddo Conference, Natchitoches, Louisiana.

Shaeffer, James B.

1957 The Nagle Site, Ok-4. Bulletin of the Oklahoma Anthropological Society 5:93-99.

Stewart, T. D.

1941 The Circular Type of Cranial Deformation in the United States. American Journal of Physical Anthropology 28:343-351.

Story, Dee Ann

1991 Some Comments on the Status of Caddoan Archaeology. In News and Views, Newsletter of the Department of Archeological Planning and Review, Texas Historical Commission 3:17-18.

Story, Dee Ann, Janice A. Guy, Barbara A. Burnett, Martha Doty Freeman, Jerome C. Rose, D. Gentry Steele, Ben W. Olive, and Karl J. Reinhard.

1990 The Archeology and Bioarcheology of the Gulf Coastal Plain, Vol. I \& II. Research Series No. 38. Arkansas Archeological Survey, Fayetteville.

Suhm, Dee Ann, and Edward B. Jelks 1962 Handbook of Texas Archeology: Type Descriptions. Special Publication No. 1, Texas Archeological Society, and Bulletin No. 4, The Texas Memorial Museum, Austin. 
Volume 7, Number 4

Suhm, Dee Ann, Alex D. Krieger, and Edward B. Jelks

1954 An Introductory Handbook of

Texas Archeology. Bulletin of the

Texas Archeological Society 25.

Austin.

Swanton, John R.

1946 The Indians of the Southeastern United States. Bulletin 137. Smithsonian Institution, Bureau of American Ethnology, Washington, D.C.

Webb, Clarence $\mathrm{H}$.

1958 A Review of Northeast Texas Archeology. Bulletin of the Texas Archeological Society 29:35-62.

Wilson, Diane E., and Sharon McCormick Derrick

1996 Cranial Modeling as an Ethnic Marker Among the Caddo. Paper presented at the 61st Annual Meeting of the Society for American Archaeology, New Orleans.

Wyckoff, Don G.

1967a The Archaeological Sequence in the Broken Bow Reservoir Area, McCurtain County, Oklahoma. Stovall
Museum of Natural History, and Oklahoma River Basin Survey Project, University of Oklahoma Research Institute, Norman.

1967b The E. Johnson Site and Prehistory in Southeast Oklahoma. Archaeological Site Report No. 6. Oklahoma River Basin Survey, Norman.

1967c Woods Mound Group: A Prehistoric Mound Complex in McCurtain County, Oklahoma. Bulletin of the Oklahoma Anthropological Society 15:1-76.

1968a The Beaver Site and the Archeology of the Broken Bow Reservoir Area, McCurtain County, Oklahoma. Archaeological Site Report No. 9. Oklahoma River Basin Survey, University of Oklahoma, Norman.

1968b The Bell and Gregory Sites: Archaeological Chronicles of Prehistory in the Pine Creek Reservoir Area, Southeast Oklahoma. Archeological Site Report No. 11. Oklahoma River Basin Survey, Norman.

\section{END NOTES}

1. But -- Brooks (1996:24) seems to say -- desirable though such a new paradigm might be, it is not likely that one will be developed now that NAGPRA is upon us, a circumstance which he takes to mean that we no longer have the luxury of indulging in mere "academic exercises" in which "conventional views" are challenged. To that I must reply that the time when "archaeological argument could be expressed as a challenge to conventional views" is not "in the past", as Brooks would have it. Quite the contrary, it will always be the business, if not the duty, 
of academics and scientists in every field to scrutinize all "conventional views", challenging them when necessary, regardless of "political reality".

2. The odd leitmotif of Brooks's critique is his argument that since a few traits from the long list of traits I used to distinguish the Arkansas Valley tradition from the Caddoan tradition south of the Ouachita Mountains are not unique to the Arkansas Valley, something I did not and need not claim, I have failed to make my case. Thus he argues at some length that stone seed grinding equipment, which I described as characteristic of the Arkansas Valley tradition but absent from the Woodland period on in the Caddo area south of the Ouachitas, was not unique to the Arkansas Valley since it occurs throughout the Southern Plains and the Southwest. Of course not. But that neither weakens nor refutes my argument. Similarly, it does not matter whether the rectangular four and two center-post houses with extended, often wall-trenched, entryways that are characteristic of the Harlan, Spiro and early Fort Coffee phases also occur on the Plains. My point is that these two house forms do not occur in the Caddo area south of the Ouachitas, where the (very sophisticated) four or two center post construction technique is generally absent.

3. I would now argue (see Schambach $1995: 13 ; 1996)$ that the Spiroans were probably getting most of their buffalo products by trade rather than by hunting. In either case, I think, bison products were a vital element in the Spiroan economy.

4. As Brooks should know, I am aware of the late radiocarbon dates that he cites as evidence that the Sheffield and Tyler-Rose sites are Fort Coffee phase. I cited them when I discussed the fact that these sites were formerly considered Fort Coffee phase but are now considered Spiro phase (Schambach 1993:199). But I put more credence in the fact that both Brown (1984:Table 11.1) and Rohrbaugh (1982:218) consider Sheffield Fort Coffee phase and that, albeit it with some hesitation, Rohrbaugh (1982:192-199) considers Tyler-Rose too early for his Fort Coffee phase, opinions I share in both cases. That doesn't make them right, of course, but it shows that my interpretations of these two sites are not as idiosyncratic as Brooks thinks.

5. Brooks's attempt to minimize the evidence for bison usage at the School Land sites by citing minimum numbers of individuals represented rather than estimated quantities of meat represented seems ludicrous. Surely he doesn't think that one deer is the equivalent of one bison. What about one rabbit? Perhaps he is trying to create the impression that I overlooked the fact that the numbers of bison bones at these sites are relatively small. But 1 did not. While bison bones are outnumbered by deer bones at these sites, they represent significant quantities of meat. To quote from my (Schambach 1993:197) summary of Duffield's (1969) data and interpretations, the bison bones at the School Land I site "comprise $2.73 \%$ of the mammal bones and account for an estimated 1,500 pounds of meat, which is $26.17 \%$ of the estimated $5,691.25$ pounds of meat represented by mammal bones (Duffield 1969: Table 1). In the collection from School Land II eight bison bones comprise $34.79 \%$ of the food refuse bone and account for $47.62 \%$ of the estimated 1,050 pounds of meat represented (Duffield 1969:Table V)." I went on to say that 
"Although these are significant totals, the actual consumption could have been higher, considering Wood's argument that people of the Steed-Kisker phase (A.D. 850-1300) in a similar ecological situation on the Missouri River near Kansas City were hunting bison even though there were no bison bones at village sites in that area. The evidence, he contends, was a hundred miles away in the form of bison bones at a Steed-Kisker hunting camp (Wood 1968:171-179)." In other words, when the subject of bison consumption comes up we must take into consideration the "schlepp effect," the possibility that, because hunters would probably leave heavy bison bones behind at kill sites, even small numbers of them at habitation sites may be indicative of considerable reliance on bison.

6. There is nothing "uncertain" (Brooks 1996:18) about where I obtained the data on bison bones at the Norman site. As my citation (Schambach 1993:198) indicates, it is in an Oklahoma Prehistorian report by Joe J. Finklestein (1940) on the excavations at Norman site. As Brown (1996:31) indicates, that report also contains important data on plant remains from Norman.

7. I am not -- as Brooks (1996:18) insinuates by remarking "I might add that there is also bison bone from the Craig and Copple mounds at Spiro" -- ignorant of the bison remains from these contexts. The Craig and Copple mound data, including the bison bones, are discussed in detail in my "Some New Interpretations of Spiroan Culture History" (1993:198), the paper Brooks is attacking on the matter of bison usage in the Arkansas Valley.

8. Brooks also states "These are not the bison scapula, innominate and horn core hoes found in Fort Coffee phase occupations" (1996:19). Evidently he does not know, although I pointed it out in one of the papers he is criticizing (Schambach 1993:197), that according to Wyckoff (1980:469 and Table 85) the earliest dated bison scapula hoes in the Arkansas Valley tradition are from the School Land I site, which seems to be securely radiocarbon dated to circa A.D.1100 and has yielded no evidence of a Fort Coffee phase occupation.

9. I would not gainsay the importance of corn in the Spiroan subsistence pattern, particularly because I suspect -- on the basis of data presented in an interesting paper by Little (1987:59-60) -that dry corn meal was the "trail food" staple that made possible the long-distance overland trade network that I envision for the Spiroans.

10. Although my new paradigm was published in 1993, Brown's 1996 volumes on Spiro were already completed by then and in press, which means that by 1992 or so, he and I had independently concluded that the Spiroan phenomenon required a different kind of explanation than Mississippian centers such as Cahokia, Moundville and Etowah.

11. As I first observed many years ago (Schambach $1982: 178 ; 1993: 192-193$ ), the use of stone seed processing equipment throughout the Woodland and Mississippi periods is another important way in which it was different, since stone seed processing equipment was not in use during that 
period in the Caddo area south of the Arkansas Valley.

And that, of course, would explain why the teeth of the skeletons from the unreported WPA excavations from the Nelson site, which Brooks brings into the discussion for reasons that are not clear to me, are, as he claims, in "wonderful condition." Since the Nelson site -- surely we're talking about the same Nelson site -- is in the Red River Valley about 20 miles northeast of the Sanders site, I would expect its occupants to have been Red River Valley Caddos and I would expect the skeletal remains from there (these have not, to my knowledge, been studied by bioanthropologists) to exhibit a dental health profile similar to that of other Red River Valley Caddos. I would also expect the crania from this site to exhibit some "occipital" -- actually, frontal-occipital -- deformation because this style of cranial modeling is, as Wilson and Derrick (1996) have recently reaffirmed, characteristic of the Caddo population of the Red River Valley. It is not, as Brooks thinks, a "classic Sanders phase" style. The Sanders site crania exhibit a markedly different "annular" or "circular" style. This has been widely known for more than fifty years (Goldstein 1940; Stewart 1941; Neumann 1942:310; Brues 1957;104).

12. As I pointed out originally (Schambach 1993:189), Fritz (1989:80-86, 1990:9-11), calls this a "non eastern complex corn." That suggests to me the possibility that it was a plant the -- in my view -- peripatetic Spiroan traders had brought from the Southwest recently, perhaps because they found that it did better than Eastern varieties in their hot, comparatively dry environment on the edge of the Eastern Woodlands in eastern Oklahoma.

13. It is "usually transmitted before puberty through direct skin-to-skin contact and the sharing of drinking vessels" (Rothschild and Rothschild 1996:556).

14. This entity has yet to be confirmed archeologically, despite its wide acceptance. Readers familiar with the literature of the Caddo area will not be surprised by this statement because I am not the first to question the status of the Sanders focus as a taxonomic unit, nor the first to reject it.

As early as 1958, Webb (1958: 49-50), who understood how "foci" or phases should be constructed, referred to Krieger's concept as "preliminary" and in need of "rounding out by studies of other sites." Specifically, he wanted "to know whether other sites exhibit the combination of Plains traits (bison hunting, bison scapula hoes, 4-edged beveled knives, stone elbow pipes), Caddoan traits, and southern cult objects described for the Sanders site."

In 1984 Brown (1984:262), whose study of the ceramics at the Spiro site (1971:145-171) and observations on the pottery from Sanders made it clear to me that much of the pottery in the graves at Sanders was Spiroan by type and probably by derivation as well (Schambach 1993:203-204), summarily wrote off the Sanders focus as a taxonomic unit, referring to it and the supposedly related "Nelson focus" in southeastern Oklahoma as "regional variants of the Spiro 
phase." That comes close to my interpretation of the Sanders mortuary collection as the result of a site unit intrusion from Spiro.

In 1990 Dee Ann Story (Story et al. 1990:302) called Krieger's treatment of the Sanders site material "preliminary, but insightful", stating (Story et al. 1990:174) that the "Sanders site needs restudy and the Sanders focus redefinition." One year later (Story 1991:17) she reaffirmed that "the oft-cited analysis of the Sanders site (Krieger 1946:172-218) is preliminary" and added that it "does not separate all components now identifiable in the artifact collections at TARL." Considering that this comes from the senior author (then Dee Ann Suhm) of the most recent formal description of the Sanders focus (Suhm, Krieger and Jelks 1954:176-182), where there is no hint that anything about it should be considered "preliminary," Story's present stance is tantamount to a retraction of the concept.

15. One of the peculiarities of the pottery in the Sanders mortuary collection compared to pottery from other Red River Valley sites is that many pots are tempered with plate-like gray inclusions that look exactly like burned shell but do not -- as I learned when I examined all of this pottery in December 1995 -- react to dilute hydrochloric acid. It is easy to see why A. T. Jackson, the excavator of the Sanders site, thought that 49 of the 74 whole pots from the graves and other contexts at Sanders were shell-tempered. (This figure is from a table titled "Data Regarding Features of Earthenware Vessels" that appears in Jackson's comprehensive but, regrettably, unpublished manuscript on the Sanders site, a copy of which is on file at the Texas Archeological Research Laboratory in Austin.) Brown (1996:129) has recently described "platelike grey inclusions that did not react to acid" as one of the important aplastics in the Spiro site pottery and has identified the mystery material as shale. Assuming, as I suspect is the case, that shale temper is not present in Caddo pottery from sites in the Sanders locality, its presence in pots in the Sanders mortuary collection would be all but conclusive evidence that they were made in the Arkansas Valley and imported to the Sanders site.

16. This is not the far-fetched conclusion it might appear to be. Krieger himself (1946:191) recognized that "Sanders pottery is quite distinct... from other Gibson Aspect Foci, in having several unique vessel forms, in the "high proportion of plain vessels", and in the "complete lack of square bases and quadration in design." He also recognized that the most obvious of the imported pots from the graves at Sanders, such as the negative painted bottle from Burial 15, were probably traded specimens. And he speculated, no doubt correctly, that Monkstown Fingernail Impressed might be a "trade ware" since it was represented by only 5 pots from the graves and refuse filled pits on the site and "some twenty" sherds from the middens. Furthermore, he recognized that "Certain ceramic features of Sanders have counterparts in Spiro and other cultures to the northeast" (Krieger 1946:216-218). These "ceramic features" were tripartite bottles, which he traced to "the central Mississippi basin" and points "eastward as far as Etowah in northern Georgia;" the "modeling of frogs (or other animals) on the side [sic] of bottles" which, he noted, appears on specimens from northeast Arkansas and on one bottle from the Crenshaw 
site; negative painting, which he recognized as "extremely rare west of the central Mississippi basin, and probably represented solely by trade pieces"; strap handled jars like the Monkstown Fingernail Impressed jars at Sanders "which have counterparts in Spiro Focus and 'Middle Mississippi' in general; limestone temper, which he thought he recognized in "at least one Sanders bowl" and which he compared to the type "Monks Mound Red then considered characteristic of the "Old Village Focus" at Cahokia, and the lugged bowls at Sanders (Krieger 1946: Plate 26,h; Plate 27d, h) which he found "somewhat remindful of 'bean pots' in Spoon River and Trappist Foci in southern Illinois."

17. Actually they are markers for the late Harlan, Norman and Spiro phases (see Brown 1996:Figure 1-51) of Spiroan culture, as Brooks himself unwittingly implies in the passage just quoted.

18. Brooks could have discovered this for himself had he -- as he made the "comprehensive review of the archaeological record" on which, he states (Brooks 1996:17), his review of my work is based -- consulted the twenty-two primary sources (see my end note 19) on the distribution of this pottery in the Red River Valley. Instead he cites as his sole authority for the supposed "abundance" of red slipped pottery in the Red River Valley a secondary source (Bruseth, Wilson and Perttula 1995) in which this topic is not discussed.

19. The sources for the data summarized in this and subsequent tables are as follows. Mackin: Mallouf 1976; Baldwin: Rohrbaugh 1968; Beaver: Wyckoff 1968a; Bell: Wyckoff 1968b; Clement: Bell and Baerreis 1951, Flynn 1976; Cook: Bell and Baerreis 1951; E. Johnson: Wyckoff 1967b; Fasken: Prikryl 1991, 1992; Gregory: Wyckoff 1968b; Harling: Davis 1962a, 1962b; Holdeman: Perino n.d.; Hines: Bruseth and Perttula 1981; Mahaffey: Perino and Bennett 1978, Rohrbaugh et. al. 1971; Spoonbill: Bruseth and Perttula 1981; Nelson: Bell and Baerreis 1951; Pat Boyd: Rohrbaugh 1973; Payne Rohrbaugh 1973; Pine Creek Mounds: Gettys 1975; Sam Kaufman (a k a Roitsch): Harris 1953, Skinner et al. 1969, Martin 1991, 1992; Woods Mound: Wyckoff 1967c; T. Moody: Perttula et al. 1988; Yarbrough: Johnson 1962; Taddlock: Bruseth and Perttula 1981.

20. Defenders of the Sanders focus concept should give some thought to the fact that this list contains only "probable" Sanders focus components. Except for the Sanders site itself, there are -after 50 years of archeological work -- no additional east Texas or southeast Oklahoma sites at which Sanders focus components have been confirmed on the basis of reasonably complete assemblages from good archeological contexts such as graves, pits, house floors or single component middens. And many of these identifications, which are necessarily based on pottery alone since other diagnostic artifacts of the "Sanders focus" are scarce as hen's teeth in the Red River Valley, are, if "probable" at all, certainly not very probable. Thus the identifications of the Clement, Fasken, Harling, T. Moody and Woods Mound sites, none of which has actually produced any pottery of "Sanders focus" types, much less other "Sanders focus" diagnostics, are 
pure guess-work. The identifications of Mackin (based on 30 sherds), Bell (on 14 sherds), Cook (on one sherd), Gregory (on 25 sherds), Hines (on 13 sherds), Kaufman (on 34 sherds), and Pine Creek (on 10 sherds) are not significantly better, particularly when the difficulties in identifying the various "Sanders focus" types from sherds (discussed below in the text) are considered.

21. Here and in subsequent discussion I am disregarding the identifications of Sanders focus pottery types in Perino's deservedly unpublished report on the Holdeman site -- Bruseth, Wilson and Perttula (1995:228) have done him no favor by citing it. My reasons are that his descriptions are inadequate (temper isn't so much as mentioned, for example) and that -- because he was new to Caddo area archeology at the time that particular manuscript was prepared and obviously knew very little about the classification of pottery, Caddoan or otherwise -- his type identifications are capricious. Since his manuscript is unillustrated it is impossible to tell what types he found in the graves at Holdeman without returning to the collection. All things considered, I doubt that it contains any pots of the types Canton Incised, Sanders Engraved and Maxey Noded Redware.

22. In any case, pottery identified as Sanders Engraved is very weakly represented compared to other types at these three sites. At Hines only 4 sherds out of a total of 13,781 were classified as Sanders Engraved. At Spoonbill there are 12 and two pots compared to a total of 25,811 sherds. And at Taddlock 290 sherds out of 18,394 are classified as Sanders Engraved.

23. They caution that their "type ascriptions are based only on design elements, without regard for temper, vessel form, and other attributes commonly included in typological classification."

24. The $\mathbf{4 5}$ sherds and one pot from the Yarbrough site are easily excluded from this total as well because none of the Yarbrough site pottery classified as Sanders Engraved is described as red slipped (Johnson 1962:227-229).

25. Story (Story et al. 1990:302) now agrees and, noting that the middens also yielded significant numbers of Gary points and double bitted chipped stone axes, suggests that the Williams Plain pertains to an "Early Ceramic component" at Sanders -- "Early Ceramic" being her idiosyncratic name for the culture that is now generally called Fourche Maline (Jeter et al. 1989:111-157).

26. The earliest slipped pottery I know of in the Red River Valley is the French Fork Incised and Coles Creek Incised pottery from the Crenshaw site. Most of the former and much of the latter is heavily slipped in shades of brown, gray and, sometimes, red.

27. According to Brown's latest compendium (1996:158-161), red filming and red slipping have a much longer history in the Arkansas Valley than that which Brooks attributes to red slipping in the Red River Valley. Brooks seems to think this trait appeared "in the twelfth century" in the Red River Valley but the earliest red filmed specimen from Spiro is a "Coles Creek Polished Plain gourd effigy bowl" pertaining to Brown's Spiro 1A period, to which he assigns a time span of 
from A.D. 1000 to A.D. 1050. "Complete red slipped coats" appeared at Spiro in the Spiro IB period, beginning at A.D. 1050, and continued into the Spiro II period, beginning at A.D. 1100.

28. The archeological data that might tell us what kind of establishments these were are lacking at both Sanders and Nagle. They could have been seasonally occupied camps rather than year-round settlements.

29. Another possibility, which I have alluded to elsewhere (Schambach 1993:207), is that some or all of them were captives who were part of the stock in trade at Nagle and Sanders.

30. Which, as I have shown here in this paper, are all strangely lacking in so-called Sanders focus pottery types, not to mention other "Sanders focus" traits.

31. See Schambach 1996 for my explanation of why annular cranial deformation also appears at Womack, where the crania exhibiting it are from historic period graves. 